\title{
MEDICAL STUDENTS MOTIVATION AFTER TAKING A POST-TEST IN PROBLEM-BASED LEARNING
}

\author{
Nola Agina Br. Ginting ${ }^{1}$, Ratih Yulistika Utami²* \\ ${ }^{1}$ Medical students, Faculty of Medicine, Universitas Muhammadiyah Sumatera Utara, Medan - INDONESIA \\ ${ }^{2}$ Medical Education Unit, Faculty of Medicine, Universitas Muhammadiyah Sumatera Utara, Medan - INDONESIA
}

Submitted: 23 May 2018; Final Revision from Author: 17 Jan 2020; Accepted: 06 Mar 2020

\begin{abstract}
Background: Student prior knowledge on the tutorial process (problem-based learning) is different from each batch, which affects the ability to determine the learning issue. Assessment is one of the factors that influence student motivation to learn in the tutorial; increasing students' motivation is an essential target in PBL. The objective of this study was to determine the effect of applying a post-test at the tutorial on students' learning motivation of FM UMSU in order to achieve the learning objectives of PBL.

Methods: This research was a quantitative study; experimental methods with post-test only control group design. This study measured the students' learning motivation using the Motivated Strategies for Learning Questionnaire (MSLQ). Samples were students of FM UMSU class 2013, divided into two groups randomly. Data were analyzed using the Mann-Whitney test.

Results: Assessment should motivate students' learning. However, in PBL, several factors that affect students' motivation as well as assessment. Those factors are group dynamics, scenario, and tutor's performance that should be controlled. The validity and reliability of the assessment are also crucial issues that affect the results. Conclusion: A proper assessment should be able to motivate students to learn. However, in PBL, several factors affect students' motivation as well as assessment, namely group dynamics, scenario, and tutors' performance that should be controlled. The assessment itself refers to their validity and reliability so that researchers should consider several issues before constructing the MCQs in PBL, for example, the content, type and timing of the assessment in order to motivate students to study harder by applying a strategic approach.
\end{abstract}

Keyword: problem-based learning, learning issues, motivation, post-test

\section{ABSTRAK}

Latar belakang: Pengetahuan mahasiswa pada proses tutorial (problem-based learning) berbeda tiap angkatan, yang berdampak pada kemampuan menentukan tujuan belajar (learning issue). Penilaian adalah salah satu faktor yang mempengaruhi motivasi belajar mahasiswa dalam tutorial. Peningkatan motivasi merupakan sasaran penting dalam PBL. Tujuan peenlitian ini untuk mengetahui pengaruh penerapan post-test pada proses tutorial terhadap motivasi belajar mahasiswa FK UMSU.

Metode: Penelitian ini merupakan penelitian kuantitatif, metode eksperimental dengan rancangan post-test only with control group. Penelitian ini mengukur motivasi belajar mahasiswa dengan Motivated Strategies for Learning Questionneire

*corresponding author, contact: ratihyulistika@umsu.ac.id 
(MSLQ). Sampel penelitian adalah mahasiswa FK UMSU angkatan 2013 yang dibagi kedalam dua kelompok secara acak. Data dianalisis menggunakan uji Mann-Whitney.

Hasil: Uji Mann-Whitney, diperoleh nilai $p=0,463$, karena nilai $p>0,05$, motivasi belajar mahasiswa yang diberikan post-test dengan yang tidak diberikan post-test tidak berbeda secara bermakna.

Kesimpulan: Penilaian yang baik seharusnya dapat memotivasi mahasiswa untuk belajar. Namun, pada pembelajaran PBL, ada faktor lain juga memengaruhi motivasi belajar mahasiswa yaitu, dinamika kelompok, skenario, dan performa tutor yang seharusnya ikut dikontrol. Penilaian itu sendiri mengacu pada validitas dan reliailitas sehingga peneliti harus mempertimbangkan beberapa hal untuk menyusun dan menerapkan ujian pilihan ganda di PBL, seperti konten, tipe dan waktu ujian agar mampu memotivasi mahasiswa untuk giat belajar dengan pendekatan belajar strategis.

Kata kunci: proses tutorial, problem-based learning, learning issue, motivasi belajar, post-test

\section{PRACTICE POINTS}

- Research on assessment in PBL is mostly a formative assessment to assess cooperation, critical thinking, and attitudes. Evaluation of students' knowledge after a PBL process is still limited in Indonesia, although there are several assessment methods used, such as Student Oral Case Analysis (SOCA), MCQ, Essays, Short Essays. This study describes the MCQ exam, which is used to assess students' knowledge after a PBL process and its effect on student motivation because an assessment is expected to encourage students to evaluate the learning process and design better learning objectives.

- The lesson learned from this study is to determine the assessment needs to be considered several things to compile and implement multiple-choice questions in PBL, such as content, type, and time of the test to be able to motivate students to active learning with a strategic learning approach, although the results of this study indicate that there is no effect of the test given on student motivation.

- There are several assessment methods used in PBL. The best assessment method should be considered the validity, reliability, and applicability of the assessment method. Multiple-choice questions have high validity and reliability, while the applicability depends on the context and objective of why the assessment used.

\section{INTRODUCTION}

Assessment of the cognitive aspects of the tutorial process differs for each year. ${ }^{1}$ The differences occur because of the first and second-year students focus on the learning issues while the third year pursues the interests and needs of personal learning. ${ }^{2,3}$ Students in the third and fourth year claim that the tutorial group is less functional than in the first and second year. This condition harms the ability to formulate learning issues, and students will be forced to determine for themselves what is important to learn. ${ }^{3}$ The results of previous research pointed to the fact that ratings motivate students to learn and influence the amount of effort required in the learning process. ${ }^{4}$ Research conducted by St George's School of Medicine, University of London (SGUL) on anatomy courses shows that there is a significant relationship between the weighting of an eye. Lecturing in an assessment scheme with the medical student's motivation on the subject's learning. ${ }^{5}$ A study of post-test impacts on junior high schools in Germany shows that exams firmly control extrinsic motivation strategies. Although this strategy has the desired effect (good outcome), it also has some side effects, such as the loss of intrinsic motivation, an increase of exam anxiety, increases pressure, and decreased self-efficacy. ${ }^{6}$ In summary, the assessment of a course using a post-test may increase the student's motivation to study the subject. Therefore, students should be stimulated to realize their level of knowledge and manage the learning process because of their motivation. ${ }^{7}$ Improving student motivation is a crucial target in problem-based learning (PBL). ${ }^{8}$ However, most PBL research examines knowledge construction, problem-solving, and self-directed 
learning. There is little research on the relationship between students' motivation and assessment in the context of PBL. The primary purpose of this study is to determine the effect of post-test implementation on the tutorial process on student motivation in order to achieve the learning objectives of PBL.

\section{METHODS}

This research is an experimental method of post-test only with control group design. The subject of this research is students from the Faculty of Medicine, Universitas Muhammadiyah Sumatera Utara, who still actively follow the tutorial activity. The sample selection used cluster sampling, where the authors randomized the research sample based on the tutorial group. In this sampling, samples were randomly selected in groups of individuals in a naturally occurring population.9 The population was 112 students. This research has been granted the research permission of Medical and Health Research Ethics Committee, Faculty of Medicine, the University of Sumatera Utara dated July 29, 2016, No: 494/TGL/ KEPK FK USU-RSUP HAM/2016. In this study, the authors used the instrument translation version of the Motivated Strategies for Learning Questionnaire (MSLQ) to measure the motivation of study subjects. This instrument consists of 31 items (questions) that assess the orientation/goals and values of students' beliefs on certain subjects, students' beliefs about their ability to succeed in a subject, and students' anxiety about the exam. This instrument consists of 7 scales: $1=$ very not true for me, $4=$ sometimes true to me, $5=$ often true for me, $6=$ is usually true for me, 7 = is very true to me. This instrument has been translated into Indonesian by an English literature expert.

Furthermore, the questionnaire was re-translated into English to see the suitability of the contents of the translation version of the MSLQ questionnaire with the original manuscript of this questionnaire. Then, the test legibility by two students outside the subject of research. The end of this stage is the validity and reliability test item (question) MSLQ questionnaire that has been filled by 20 students outside the research subject. The instrument reliability test results found that the value of Cronbach's alpha $=$ $0.856(\geq 0.7)$ means that the instrument is reliable and capable of measuring the motivation of learning consistently. In the instrument validity test found Pearson Product Moment correlation value <0.3 on some items (question), then the item in this instrument is declared invalid. The invalid items contained in numbers $2,3,8,9,13,14,19,23$, and 28 mean there are only 22 valid items to measure the subject's learning motivation. The authors made the question for the post-test with the guidance of the lecturer in charge of the ongoing block during the research, i.e., tropical medicine (block 19). The authors made 15 questions that correspond to the hypothesis in the ongoing tutorial during the research. Authors performed the treatment for 35 minutes with details: provided an explanation sheet to the prospective subject and student consent form to be the subject of the study (5 minutes); gave the subject time to do post-test (15 minutes); gave the subject time to fill out the MSLQ questionnaire (15 minutes). In the control group, the authors gave an explanatory sheet to the prospective subject, a student consent form to be the subject of the study, and the MSLQ questionnaire. The data was collected at the end of the second-day tutorial meeting. The data of this study were tested for normality using the Kolmogorov-Smirnov test. The data distribution was not normal then the authors used a Mann-Whitney test.

\section{RESULTS AND DISCUSSION}

Mann-Whitney test result showed that the motivation score between the two groups had $p=0,463$ ( $p>$ $0,05)$, which means that there was no significant difference in motivation between students who were given post-test and were not given post-test. Table 1 shows the results of the motivation score analysis of both groups. 
Table 1. Mann-Whitney test

\begin{tabular}{cc} 
& P-value \\
The score of motivation in the intervention and control group & 0,463 \\
\hline
\end{tabular}

Table 2 shows the subjects' characteristics by sex, academic achievement, post-test score, and motivation score.

Table 2. Subjects' characte

\begin{tabular}{|c|c|c|c|c|}
\hline \multirow{2}{*}{ Characteristic } & \multicolumn{2}{|c|}{ Intervention group } & \multicolumn{2}{|c|}{ Control group } \\
\hline & Frequency $(\mathrm{N})$ & Percentage (\%) & Frequency $(\mathrm{N})$ & Percentage (\%) \\
\hline
\end{tabular}

Sex

$\begin{array}{lllll}\text { Female } & 40 & 71,4 & 46 & 82,1 \\ \text { Male } & 16 & 28,6 & 10 & 17,9\end{array}$

Academic achievement

$\begin{array}{lcccc}<2.00 & 0 & 0 & 0 & 0 \\ 2.00-2.75 & 7 & 12,5 & 14 & 25 \\ >2.75 & 49 & 87,5 & 42 & 75\end{array}$

Post-test value

$\begin{array}{lcccc}80-100 \text { (Good) } & 22 & 39,3 & 0 & 0 \\ 60-79(\text { Enough }) & 20 & 35,7 & 0 & 0 \\ 40-59(\mathrm{Bad}) & 14 & 25 & 0 & 0\end{array}$

Motivation score

\begin{tabular}{lllll}
$30,0-35,9$ & 23 & 41,1 & 15 & 26,8 \\
$24,0-29,9$ & 20 & 35,7 & 30 & 53,6 \\
$18,0-23,9$ & 13 & 23,2 & 11 & 19,6 \\
\hline
\end{tabular}

Table 3 shows the description of students' motivation. i.e., five scales (often accurate for me) from 7 scales The mean of students' motivation was high enough, (is very accurate to me).

Table 3. Description of subjects' motivation

\begin{tabular}{lcc} 
Component & Mean & Standard deviation \\
Intrinsic motivation & 5,08 & 1,07 \\
Extrinsic motivation & 5,83 & 1,00 \\
Task value & 5,49 & 0,95 \\
Control of learning & 5,95 & 1,06 \\
beliefs & & \\
Self efficacy & 5,32 & 0,94 \\
\hline
\end{tabular}


Table 4 shows the mean motivation between intervention and control groups. The mean motivation in the intervention group was 28.00, although in the control group was 27.5. The difference means between the intervention and control group was 0.5. It means that there was no significant difference in the mean of students' motivation.

Table 4. Mean of motivation component

\begin{tabular}{lcccccc} 
& \multicolumn{5}{c}{ Mean of motivation component } \\
\cline { 2 - 7 } \multicolumn{1}{c}{ Groups } & Intrinsic & Extrinsic & Task Value & $\begin{array}{c}\text { Self- } \\
\text { Efficacy }\end{array}$ & $\begin{array}{c}\text { Control of } \\
\text { learning beliefs }\end{array}$ & Total mean \\
Intervention & 5,24 & 5,78 & 5,57 & 5,34 & 5,97 & 28 \\
Control & 4,93 & 5,88 & 5,42 & 5,3 & 5,93 & 27,5 \\
\hline
\end{tabular}

Table 5 shows the distribution of post-test scores based on sex, academic achievement, and motivation score. Subjects whose the post-test score were good, have bad motivation score $(18,0-23,9)$. Subjects whose post-test scores were enough, have a good motivation score $(30,0-35,9)$. Subjects whose the post-test score were bad, have enough motivation score.

Table 5. Post-test score in intervention group

\begin{tabular}{|c|c|c|c|c|c|c|}
\hline \multirow{5}{*}{ Characteristic } & \multicolumn{6}{|c|}{ Post-test score } \\
\hline & \multicolumn{2}{|c|}{ Good } & \multicolumn{2}{|c|}{ Enough } & \multicolumn{2}{|c|}{ Bad } \\
\hline & \multicolumn{2}{|c|}{$(80-100)$} & \multicolumn{2}{|c|}{$(60-79)$} & \multicolumn{2}{|c|}{$(40-59)$} \\
\hline & Frequency & Percentage & Frequency & Percentage & Frequency & Percentage \\
\hline & $(\mathrm{N})$ & (\%) & $(\mathrm{N})$ & (\%) & $(\mathrm{N})$ & (\%) \\
\hline \multicolumn{7}{|l|}{ Sex } \\
\hline Female & 15 & 37,5 & 15 & 37,5 & 10 & 25 \\
\hline Male & 7 & 43,8 & 5 & 31,3 & 4 & 25 \\
\hline \multicolumn{7}{|l|}{$\begin{array}{l}\text { Academic } \\
\text { Achievement }\end{array}$} \\
\hline$<2.00$ & 0 & 0 & 0 & 0 & 0 & 0 \\
\hline $2.00-2.75$ & 1 & 14,3 & 4 & 57,1 & 2 & 28,6 \\
\hline$>2.75$ & 21 & 42,9 & 16 & 32,7 & 12 & 24,5 \\
\hline \multicolumn{7}{|l|}{ Motivation score } \\
\hline $30,0-35,9$ & 7 & 30,4 & 12 & 52,2 & 4 & 17,4 \\
\hline $24,0-29,9$ & 6 & 30 & 6 & 30 & 8 & 40 \\
\hline $18,0-23,9$ & 9 & 69,2 & 2 & 15,4 & 2 & 15,4 \\
\hline
\end{tabular}

From the results of the study through statistical tests found no significant difference in learning motivation between students who were given a post-test with those who were not given a post-test. The results of this study are different from the results of research Van Etten et al. found that the assessment motivates students to learn and affect the amount of effort required in the learning process. 4 Assessment should be constructed to motivate students to study optimally. The value of a test and 
the expectations students have are vital motivational factors. ${ }^{10}$ To achieve motivation, students should receive an adequate stimulus to study harder, i.e., an opportunity to compensate unsatisfied result with a high mark. Sometimes, students felt more motivated when it is a summative assessment, while the current study stated that students would take some test which accumulates their grade at the end of the program, instead of taking the high stakes test. ${ }^{10}$

However, assessment is one of the extrinsic factors influencing students' motivation. Two factors influence the motivation of one's learning, the intrinsic factors in the form of pleasure in studying, the impetus to be the best, and the student's belief in his ability and extrinsic factors in the way of encouragement of parents, supervisors, friends, and learning environment. ${ }^{6,10,11}$

The intrinsic factor in the results of this study can be measured through the MSLQ questionnaire in the intrinsic motivational component of item 1 , 16, 22, and 24. The mean component of intrinsic motivation in the intervention group and the control group is found to be on a scale of 5 which has an "Accurate for me." This high average value indicates that intrinsic motivation is not the main factor affecting student's learning motivation in this research. While from the side of extrinsic factors, the drive to perform various actions will occur when there is a particular spur. These boosters can be information, advice, trust, warnings, or pilots.11 Parental encouragement as a person who is very close to the child will significantly determine the way/achievement of the child. Indifferent parents will cause the child to feel unmotivated to learn. On the contrary, children who are regularly cared for by parents will have higher interest and attention to the lesson. ${ }^{13}$ A responsive, friendly lecturer will encourage students to be open, and it is essential to improve students' learning spirits in learning. ${ }^{13}$ The encouragement of friends has a tendency dominant against one's attitude. Friends who diligently learn will affect a person's behavior. Conversely, friends who like to stay lazy can also change one's attitude. ${ }^{13}$

The learning environment in the process of tutorial consists of components that play a role in influencing student learning motivation that is the scenario, tutor, and small group collaboration. A good scenario provides feedback that allows students to evaluate the effectiveness of their knowledge, reasoning, and learning strategies. The problem solving of the scenario should motivate the students' need for inquisitiveness and learning..$^{14}$ The quality of scenarios affects not only the quality of small group discussions but also the time spent on self-study and interest in a lesson. Therefore, a scenario should be: (1) authentic, (2) adapted according to the student prior knowledge, (3) triggering students to discuss, (4) directing to appropriate learning issues, (5) stimulating self-directed learning, and (6) drawing.15 Tutors in the tutorial process are responsible for motivating students and monitoring small group processes. This monitoring ensures that all students are involved and encourages them to share their thoughts and comment on each other opinions. ${ }^{14}$

Tutors who master the material under discussion affect the student learning process, where the tutor has enough knowledge to guide the student in the process of identifying what is essential to learn. Not just mastery in the material, a tutor must also be able to make social adjustments. The social adjustment refers to the ability to communicate with students informally and empathize as well as the ability to create a learning environment that encourages the exchange of ideas between students. ${ }^{15}$ Thus, tutors who are socially adjusted and have a good mastery of the material will motivate students to achieve better. Collaboration in a small group of tutorials positively affects the learning motivation of the subject matter being discussed. The advantages of learning in groups are: (1) feeling more motivated, (2) obtaining emotional support, (3) assisting in clarifying difficult concepts and correcting misconceptions.15 Thus a small, self-directed, And in-depth material discussions can motivate and stimulate students in the learning process. ${ }^{14,16}$

The absence of influence of post-test application to students' motivation significantly can also be caused by (1) questionnaire, validity test and reliability of MSLQ questionnaire got examine of construct validity that fulfill the criterion of construct validity hypothesis only on some items (question) from motivation component extrinsic, task value, and 
control of learning beliefs, whereas in the anxiety test component no item meets the criterion of construct validity hypothesis. That condition may lead to an MSLQ questionnaire in this study not fully able to describe student learning motivation. As Lisiswati, Sanusi \& Prihatiningsih's research ${ }^{17}$ on the motivational relationship and medical student learning result also using the MSLQ questionnaire, there are only 3 of 6 motivational components that meet the criteria of construct validity hypothesis, namely intrinsic motivation component, self-efficacy, and anxiety test. These influenced the results of the study, which showed a weak correlation between motivation and learning outcomes of medical students. ${ }^{17}$ (2) The research time, the student may not be motivated again when filling the questionnaire. This research is done after the tutorial process, where the students have other activities after the tutorial activity so that the students do not concentrate again, fill the MSLQ questionnaire. The schedule of assessment impacts the distribution of learning efforts, ${ }^{18}$ (3) The number of experiments because the post-test is given only once; this may not affect student learning motivation. Post-test delivery at any second-day tutorial meeting on a block may provide a better picture of student motivation. Shumway \& Harden's research shows that an assessment should be applied in various frequencies to ensure that the samples used to provide reliable and valid results. ${ }^{19}$ As the Apranadyanti study can measure respondents' motivation effectively by piloting more than one time at 1 -month intervals, ${ }^{20}$ (4) Type of assessment of learning outcomes, in this study the application of post-test does not enter the weight of the assessment so that student learning motivation may not be affected. Post-test implementation as a summative assessment may improve student's motivation to learn. Most research results found that the application of summative assessment has the potential to influence student motivation factors such as self-efficacy and self-regulation. ${ }^{21}$ (5) Assessment task or content, Content relates to the knowledge required to respond to an assessment task. Students who were intrinsically motivated to understand content perceived an assessment to require memorization, they would memorize facts after having \rst understood them. ${ }^{18}$ Guessing and "cueing" are other issues associated with MCQs. Increasing the number of appropriate response options, however, is a straightforward way to address these issues. However, MCQs offers high internal consistency reliability because it allows for a broad sampling of content domains and high validity if they are constructed appropriately. ${ }^{22}$ Multiplechoice questions can be used to assess all three levels in the knowledge structure that can be targeted by assessment of problem-solving: understanding of concepts, understanding of the principles that correlate concepts, and association of concepts and principles to conditions for application. PBL had the most positive effects when the focal constructs being assessed were at the level of understanding the principles that link concepts, the second level of the knowledge structure. ${ }^{24}$ In this study, the MCQs were used for assessing all three levels of that knowledge structure, which was an analysis process using a stem that consists of a vignette model based on cases with five options. However, in the current studies using the multiple-choice format, the focus was on reproduction. As a consequence, all multiple-choice questions were classiled as assessing the Irst level of the knowledge structure that might demotivate students. ${ }^{23}$

Other factors that can affect the results of the assessment of learning motivation and post-test is the effect of Hawthorne. The Hawthorne effect is the effect gained from the response of the subject where the subject becomes better for a while as the subject of the study. To minimize the effects of Hawthorne on the experimental design, the researcher could use more than one experimental group in the study. ${ }^{25}$ In this study, there were six experimental groups so that there may be few Hawthorne effects affecting the study. The researcher suggested paying attention to the factors that influence student's learning motivation so as not to bias the result of research, to change the instrument of data collection with other learning motivation questionnaires, or another method that able to describe the learning motivation better. The researcher also suggested that data collection time is done outside the tutorial hours so that the respondent concentrates more on doing a post-test or questionnaire and giving a post-test at the end of the second-day tutorial meeting for one block. 


\section{CONCLUSION}

The authors conclude that the assessment should motivate students' learning. However, in PBL, several factors affect students' motivation as well as assessment. Those factors are group dynamics, scenario, and tutor's performance that should be controlled. The assessment itself refers to their validity and reliability so that researchers should consider several issues before constructing the MCQs in PBL, for example, the content or which learning objective should be assessed, type, and timing of the assessment, whether it is summative or formative. Those issues make sense because students are motivated to study harder dan more strategically in a specific subject if they realize that it will be assessed.

\section{COMPETING INTERESTS}

The authors declare that there are no competing interests related to the study.

\section{AUTHORS' CONTRIBUTIONS}

Nola - conceived of the original idea, performed the analytic calculations, and wrote manuscript; Ratih - verified the analytical methods, supervised the project, provided feedback and helped shape the research, analysis and manuscript.

\section{REFERENCES}

1. Dochy F, Segers M, Van den Bossche P, Gijbels D. Effects of problem-based learning: a metaanalysis. Learning and Instruction [serial on the internet]. 2003 Oct [cited 2016 May 25]. Available from: www.elsevier.com/locate/ learninstruc

2. Dolmans DHJM, Schmidt HG, Gijselaers WH. The relationship between student-generated learning issues and self-study in problem-based learning. Instr Sci. 1995; 22(4):251-67.

3. Van den Hurk MM, Wolfhagen IHAP, Dolmans D, van der Vleuten CPM. The impact of studentgenerated learning issues on individual study time and academic achievement. Med Educ. 1999; 33(11):808-14.
4. Cilliers FJ, Schuwirth LWT, Herman N, Adendorff HJ, Van der Vleuten CPM. A model of the pre-assessment learning effect of summative assessment in medical education. Health Sci Educ. 2012; 17:39-53.

5. Wormald BW, Schoeman S, Somasunderam A, Penn M. Assessment drives learning: An unavoidable truth?. Anat Sci Educ. 2009; 2:199. 204.

6. Jurges H, Schneider K, Senkbeil M, Carstensen $\mathrm{CH}$. Assessment drives learning: the effects of central exit exams on curricular knowledge and mathematical literacy. Economics of Education Review. 2012; 31:56-65.

7. Dolman D, DeGrave W, Wolfhagen I, Vleuten VD. Problem-based learning: future challenges for educational practice and research. Med Educ. 2005; 39:732-41.

8. Nugent JH, Crews D. A case study in direct and indirect assessments of student learning outcomes: Is there one best method?. Social Sciences Research Network [serial on the internet]. 2013 Apr [cited 2016 May 16]. Available from: http://ssrn.com/abstract=2248873

9. Sastroasmoro S, Ismael S. Dasar-dasar metodologi penelitian klinis. 5th ed. Jakarta: Sagung seto; 2014.

10. Dario Cecilio-Fernandes, Janke CohenSchotanus \& René A. Tio. Assessment programs to enhance learning, Physical Therapy Reviews. 2017. DOI: $10.1080 / 10833196.2017 .1341143$.

11. Tim Pengembangan Ilmu Pendidikan FIP-UPI. Ilmu \& aplikasi pendidika: Ilmu pendidikan teoritis. 2nd ed. Bandung: PT. Imtima; 2007.

12. Upoyo AS, Sumarwati M. Analisis fakor-faktor yang mempengaruhi motivasi mahasiswa profesi ners jurusan keperawatan Unsoed Purwokerto. The Soedirman Journal of Nursing. 2011;6(2):8187.

13. Herijulianti E, Indriani TS, Artini S. Pendidikan kesehatan gigi. Jakarta: EGC;2002.

14. Hmelo-Silver CE. Problem-based learning: what and how do student learn?. Educational Psychology Review. 2004; 16(3):235-66. 
15. Schmidt HG, Rotgans JI, Yew EHJ. The process of problem-based learning: what works and why. Med Edu. 2011;45:792-806.

16. Dolmans DHJM, Schmidt HG. What do we know about cognitive and motivational effects of small group tutorials in problem-based learning? Advances in health sciences education. 2006; $11: 321-336$.

17. Lisiswati R, Sanusi R, Prihatiningsih TS. Hubungan motivasi dan hasil belajar mahasiswa kedokteran. Jurnal pendidikan kedokteran indonesia. 2015;1(4):1-6.

18. Cilliers, FJ., Adendorff HJ., Schuwirth LW., Vleuten CPM., Herman N. A model of the pre-assessment learning effects of summative assessment in medical education. Advance in Health Science Education. 2012, 17:39-53.

19. Shumway JM, Harden RM. The assessment of learning outcomes for the competent and reflective physician. Taylor\& Francis Health Sci. 2003:569-84.

20. Apranadyanti N. Hubungan antara regulasi diri dengan motivasi berprestasi pada siswa kelas X
SMK Ibu Kartini Semarang [thesis]. Semarang: Diponegoro University; 2010.

21. Moss CM. SAGE handbook of research on classroom assessment. New York: SAGE publications inc; 2013.

22. Nendaz MR \& Tekian A. Assessment in Problem-Based Learning Medical Schools: A Literature Review. Teaching and learning in Medicine. 1999 11(4):232-243.

23. Gijbels D., Dochy F., Van de Bossche P., Segers M. Effects of Problem-Based Learning: A MetaAnalysis From the Angle of Assessment. Review of Educational Research. 2005, 75( 1). 27-61.

24. Walker A., Leary H. A Problem Based Learning Meta-Analysis: Differences Across Problem Types, Implementation Types, Disciplines, and Assessment Levels. The Interdisciplinary Journal of Problem-based Learning. 2009. 3(1).

25. Wood MJ, Ross-Kerr JC. Basic steps in planning nursing research. 6th ed. Massachusetts: Jones\&Bartlett publishers; 2006 